\title{
Varicella Infection as a Congenital Health Threat: A Narrative Review
}

\author{
Khadije Rezaie Keikhaie ${ }^{1}$, Fereshteh Javadian ${ }^{2,{ }^{*}}$ and Aliyeh Sargazi ${ }^{2}$ \\ ${ }^{1}$ Maternal Fetal Medicine, Obstetrics and Gynecology, Maternal and Fetal Health Research Center, Zabol University of Medical Sciences, Zabol, Iran \\ ${ }^{2}$ Zabol University of Medical Sciences, Zabol, Iran \\ "Corresponding author: Zabol University of Medical Sciences, Zabol, Iran. Email: fereshteh.javadian@yahoo.com
}

Received 2017 July 23; Revised 2019 July 17; Accepted 2019 July 22.

\begin{abstract}
Even though varicella is rare in pregnancy, if it occurs, it may be associated with a high rate of mortality and morbidity for both mother and newborn. Studies show that maternal infection causes congenital varicella syndrome, which could be presented with neonatal malformations such as limbs hypoplasia, skin scarring, and visual defects. This disease is more dangerous in the case of association with pneumonia, bacterial superimposed infections, and hemorrhage. Therefore, it is suggested that any varicellaexposed pregnant woman at any gestational age receives prophylactic varicella immunoglobulin. This paper deals with the clinical consequences and the available methods of prevention, diagnosis, and treatment of varicella-zoster virus infection during pregnancy.
\end{abstract}

Keywords: Health Threat, Varicella, Infection

\section{Context}

Varicella is an acute infectious disease caused by the Varicella-Zoster Virus (VZV). The recurrent infection, herpes zoster (also known as shingles), has been known since ancient times. The primary varicella infection (chickenpox) was not distinguished from smallpox until the end of the 19th century. In 1875, Steiner discovered that chickenpox is caused by an infectious agent when inoculating volunteers with the vesicular fluid from a patient with acute varicella. Clinical experiments on the relationship between varicella and herpes zoster were conducted in 1888 by von Bokay; in this study, children without evidence of varicella immunity were infected by varicella after contact with herpes zoster patients. VZV is an opportunistic pathogen that causes severe infection in immunocompromised patients. It also causes latent infection in these patients. Two main diseases are caused by this pathogen including common varicella, known as chickenpox, and herpes zoster (HZ) (1). It is also important in pregnancy because it influences the fetus and shows abnormalities as seen in $2 \%$ of pregnancies with VZ infection in the first 20 weeks of gestation. Moreover, any infection in the third trimester can cause severe infection in newborns (2). This disease could be prevented by live attenuated vaccines that were introduced in the 1970s. Many studies show that the vaccine is effective in creating a long-lasting immunity. The chickenpox vaccine is part of children routing vaccination program in many countries while there is no vaccination plan in Iran (3-7).

\section{Epidemiology}

The VZV is transmitted person-to-person via the respiratory system; therefore, close contact with varicellainfected individuals is one of the main ways of its spread. The infection risk is 10\% - 35\% in school exposure and 90\% in home exposure (8). It is worldwide distributed with more prevalence in temperate climates and less frequency in tropical areas. The annual epidemics of this infection occur at the end of winter and spring (9). Almost all children are infected in temperate areas. For example, the varicella annual incidence is nearly equal to the birth rate in the United States. The susceptibility in adults is only $5 \%$ in temperate climates. However, half of the adults in tropical regions are susceptible because of no childhood exposure (10). Restriction endonuclease analysis is a technique used for providing evidence of epidemiological characteristics of varicella such as prevalence and virulence (11).

$\mathrm{HZ}$ appears in persons with a history of varicella. Unlike varicella-zoster, HZ does not exhibit any particular seasonal pattern. Studies show that the old age and the white race are the risk factors of $\mathrm{HZ}(12)$. The $\mathrm{HZ}$ incidence was reported 3.4 cases per 1,000 population on average; it was 10 per 1,000 in adults older than 75 years and rare in children $(13,14)$. HZ is seen in children under one-year-old 
with a history of congenital varicella because of maternal infection in pregnancy $(15,16)$. HZ is more common among immunocompromised patients including immunodeficient patients and those receiving immunosuppressive medications (17). It is mostly seen in malignancies such as leukemia, Hodgkin's disease, non-Hodgkin's lymphoma disease, oat cell carcinoma of the lungs, and hematologic diseases such as systemic lupus erythematosus and rheumatoid arthritis (18). This infection has a close association with AIDS; therefore, HIV infection should be screened if $\mathrm{HZ}$ is positive.

Chickenpox (or primary VZV infection) is a routine childhood disease that usually causes a mild infection. Above $90 \%$ of people over 15 years of age in England and Wales were positive for VZV immunoglobulin G (IgG) antibody in their blood sera (19). Observations on pregnant women in Spain and France showed the immunity rate of 96.1\% and 98.8\% to varicella, respectively. Although the possibility of contact with varicella is common during pregnancy, especially in women who have children, primary VZV infection is rare in pregnancy. The probability of this infection is 3 per 1,000 pregnancies (20). Considering the high probability of negative titer of serum IgG in women living in tropical and temperate regions, they are more sensitive to chickenpox during pregnancy (21).

The presence of pneumonia complicates varicella in pregnancy and its rate has been recorded 10\% - 14\% (22) in small-scale studies. In a study on 347 cases of varicella infection in pregnancy, $5 \%$ of women were found with pneumonia (23). Generally, the mortality rate of varicella pneumonia in pregnancy in the English literature was 28/10 (36\%) in the pre-antiviral period, which may reflect publication bias (24). Recent case-based studies reported that the mortality rate is $0 \%-14 \%$, which reflects the advancement of antiviral treatments and improved patient care $(25,26)$. In the UK, nine indirect deaths and one direct death were recorded due to the complications of varicella infection between 1985 and 1999 (27). These results indicate a low mortality rate. Mothers' deaths in confidential investigations have not been reported since then.

\section{Zoster in Pregnancy}

The uterine-related dermatomes are innervated in T10 - L1 spinal segments; therefore, it is expected that these dermatomes are at a higher risk of infection during pregnancy although this theory has not been proven clinically (28). Moreover, prospective studies showed that most neonates were born healthy to mothers with the experience of varicella at any gestational age. However, a few cases were reported with congenital varicella syndrome $(16,29)$. There- fore, all mothers exposed to varicella infection should receive prophylactic immunoglobulin.

\section{Congenital Varicella Syndrome}

The congenital varicella syndrome (CVS) is presented in neonates with malformations such as limb hypoplasia and skin scarring (30). The CVS would be associated with visual problems. The granulomatous tissue is seen to cover the face from forehead to eyes. Eyelashes, conjunctiva, and cornea are damaged, too. Cornea opacification and vascularization are particularly seen. On the other hand, varicella will cause limbs atrophy, limbs hypoplasia, and skin scarring.

There are studies demonstrating the association of maternal immunoglobulin with CVS $(16,31,32)$. Moreover, a study by Orenstein et al. compared neonates whose mothers had contracted varicella at the gestational age of twentieth or thirteenth week and received or not received its immunoglobulin, showing that CVS was significantly less frequent in the former group (33). A similar study was conducted by Mouly et al. to assess the relationship between CVS and immunoglobulin injection in mothers who had contracted varicella in the first 24 weeks of pregnancy (34). In contrast, the study by Miller et al. showed that maternal varicella infection near delivery did not lead to neonatal varicella. Combining the data from the above-mentioned studies shows that out of 640 women with varicella experience during pregnancy, 142 received and 498 did not receive immunoglobulin. Among all newborns, only were 14 diagnosed with CVS, all of whom were born to mothers who had not received varicella-zoster immunoglobulin. In conclusion, the Fisher exact test showed a significant relationship between CVS and maternal immunoglobulin.

Varicella-zoster immunoglobulin (VZIG) prevents maternal infection but its role in fetal prevention has not been proven yet. In a study by Enders on pregnant women, the fetal infection was not seen in varicella-exposed mothers who had received VZIG (16). This finding was not statistically significant because of the small sample size of the study.

Although the preventive role of immunoglobulin is a matter of controversy, all exposed mothers at any gestational age should receive VZIG (35).

\section{Neonatal Varicella}

Chickenpox is an acute disease that manifests different symptoms from a mild febrile disease with skin vesicles to a complicated disease with pneumonia and hemorrhage. 
In $30 \%$ of neonates, chickenpox is associated with complications and mortality, especially if the neonate did not acquire mother-to-child passive immunity (36). Pneumonia is more common among adults but if it happens in children, it will be associated with sepsis (37). A study on two chickenpox-infected neonates with pneumonia and bacterial superimposition showed that both cases were lethargic and had tachycardia, tachypnea, hyperthermia, and leukocytosis with high nucleated white cell count. Chickenpox was presented with papulovesicular rashes associated with pus discharge in the case with bacterial superimposition. The arterial blood gas analysis showed hypoxia in the neonate with pneumonia and metabolic acidosis in the case with bacterial superimposition. Chest X-ray showed consolidations in both cases but more severe wide-speared patchy consolidation appeared in the neonate with pneumonia. In the case with pneumonia, the mother showed chickenpox rashes four days following chickenpox presentation in her neonate while the mother of the neonate with superimposed infection had presented chickenpox one day before delivery.

\section{Prevalence}

Being aware of the epidemiology of varicella helps us in planning proper control and vaccination programs. Although a higher rate of varicella infection is reported among children, more susceptibility to VZ is seen at older ages. For example, studies show that $46 \%, 75 \%, 83 \%$, and $94 \%$ of total VZV infected cases were five, five to nine, ten to fourteen, and ten-years-old in Switzerland, Spain, Italy, and Germany, respectively (38).

Seropositivity is directly correlated with age as its rate increases with age from $18.4 \%$ to $93.0 \%$ in patients aged 2 - 5 years and more than $75 \%$ in adults (39). In a study reported from Iran, this correlation was higher than what we mentioned before. The prevalence of VZ infection and complications is considerably high worldwide; therefore, VZ vaccination is proposed to decrease the varicella-related socioeconomic burden. For example, the vaccination program in the United States decreased by almost $85 \%$ of newly infected cases. In another study conducted in Iran, more than two-thirds of cases were seropositive and the VZ antibodies level was directly associated with age; therefore, susceptibility decreased in older patients. Approximately, 25\%, 43\%, 73\%, and $87 \%$ were seropositive in $1-5,6$ $-10,11-15$, and 16 - 20 age groups $(40,41)$. This is in coordination with the results by Taghavi Ardakani et al. who conducted a study on serum antibodies in children aged 115 years. They showed that the IgG antibody prevalence increased by $17 \%$ with each year increase in age in this population. The seropositivity is almost two times more in fam- ilies with more than four members than in smaller families; it is almost 40 times more in children with a history of chickenpox (42).

In different studies conducted in Iran, seropositivity was reported $42.5 \%$ in children aged 1-16 in Tehran in 2009 while it was $59.7 \%$ in children aged less than 10 years, $60.4 \%$ in children of 10 - 14 years old, and $87.5 \%$ in 15 - 19-year-old cases in Tehran in 2005 (43). A study conducted in Shiraz, located in a tropical area, showed that $35.2 \%$ of schoolchildren aged 6 - 10 years were seropositive while in another study conducted four years later in the same city, seropositivity was $25.3 \%, 43.1 \%, 73.5 \%$, and $86 \%$ in children in age groups of 1- 5, 6 -10,11-15, and 16 -20, respectively (44).

Similar studies were conducted in Pakistan, Thailand, Singapore, and West India on serum immunoglobulin of children aged 1 - 15 years and reported that $37.4 \%, 52.3 \%, 20 \%$, and $10 \%$ of their subjects were seropositive, respectively $(21,45,46)$.

The seroprevalence was 93\%, 45.8\%, $94.2 \%, 85 \%$, and $96.1 \%$ in children under five from the Netherland, under 10 from the United Arab Emirates, Germany, Turkey, and under 12 from Switzerland, respectively (38, 39, 47-49). Considering the high rate of VZV infection, the $\mathrm{HZ}$ infection rate is potentially high, as well. It is demonstrated that the incidence of hospitalization was 4.4 - 16.1 per 100,000 HZinfected patients $(50,51)$. The wild type of $\mathrm{HZ}$ induces severe infection, neuralgia, and meningitis, particularly in immunocompromised patients (52). Accordingly, trials have been conducted to find the prevention methods. It has been shown that a high titer booster dose of VZV vaccine could be preventive at older ages $(53,54)$. Moreover, patients who had vaccinated against VZV showed less complicated HZ infection than the non-vaccinated group (55). Preventive varicella vaccination is cost-effective; therefore, it is suggested for children.

The data from past decades show that varicella was on the rias among adults while recent studies show the opposite trend $(50,56)$.

The pneumonia incidence is $0.32-1.36$ per lakh in adult patients (57). The radiographic findings are presented in $5 \%-50 \%$ of adults with varicella associated pneumonia (57). The most radiographic findings include interstitial and nodular infiltrations, which are more frequent among pregnant women $(58,59)$.

Immunocompromised patients and VZV-infected patients are at higher risk of pneumonia (60). Varicellarelated pneumonia is presented one week after appearing first rashes along with fever, cough, chest pain, dyspnea, tachypnea, and hemoptysis $(61,62)$. Often when the symptoms are present, the radiologic findings are present, too (63). Even though there is a vast range of symptoms, they are not prognostic and may not be used for respiratory fail- 
ure prediction (64).

Moreover, pneumonia itself is a cause of new respiratory diseases. In this case, smoking is considered a risk factor. Smoking makes patients more susceptible to viral infections, especially herpes infection (65). Skin spots appearance more than 100 in numbers is a prognostic factor for severe pneumonia and related viremia. Another factor that is associated with pneumonia is the history of contact. It is shown that children who acquire infection from their families develop more severe varicella. This could be related to the first inhaled infectious dose (8).

On the other hand, the high incidence of pneumonia and associated fever is observed in the third trimester of pregnancy. Many reasons explain this change such as fetus pressure on the thorax and Similar to pregnancy, the incidence of varicella- associated pneumonia is increaseds in other immunocompromised diseases. It also increases in chronic obstructive pulmonary disease (6).

\section{Vaccination}

Varicella vaccines are highly effective against the prevalence and pathogenicity of the disease (66). The vaccine is kept frozen. In 1984, the license was issued for the first commercial varicella vaccine. This vaccine was the first varicella vaccine that could be kept in a refrigerator. Its development began in 1991 and it has been licensed since 1994 (67). Although it is not universally accepted, the World Health Organization suggests that countries with high prevalence should place varicella vaccine in their vaccination program (66).

Most commonly, the first dose is given at 12 - 18 months of age; if approved, the second dose is scheduled at the age of $4-6$ years. Alternatively, if the first dose $(68,69)$ lasts three months or longer, a second dose can be given in children under the age of 4 , although a lower interval is assumed to be desirable in terms of epidemiological effect. Some countries need more time to get better in vaccination programs in childhood (68).

A single-dose vaccination program is effective for controlling severe diseases, but it is not enough as the progression of varicella may be observed (70, 71). Additionally, adding the second dose seems necessary to create more safety. The economic value of vaccination programs based on one or two doses has been widely discussed $(72,73)$, but national choices ultimately depend on priorities on vaginal exclusion or the prevention of severe illness. In addition, a modeling study in Italy showed that the coverage, effectiveness, dosage or dose interval, and high coverage were the main factors behind success (74). The World Health Organization recommends that vaccination coverage should be more than $80 \%$ to be successful (66).
There is no sufficient evidence of varicella-zoster immunoglobulin (VZIG) role in healthy individuals while trials on immunocompromised patients showed reductions in rates and disease complications (75). The associated risk between passive immunity and VZIG is low (76). Pregnant women are intensively at the risk of varicella-zoster infection. If the close contact happens, serum immunoglobulin (IG) should be measured without hesitation. If the IG level is low, undetermined, or unknown, VZIG should be injected in 96 hours. The exact timing is in controversy. Studies showed a reduced rate of fetal infection and maternal chickenpox (17). However, some studies showed that half of the mothers infected with varicella-zoster and receiving VZIG presented clinical varicella. Therefore, we can conclude the VZIG can reduce varicella complications but cannot eliminate it totally.

\section{Chickenpox in Pregnancy}

A first-trimester abortion is not associated with chickenpox (77, 78). Before 24 weeks of pregnancy, vertical transmission to the fetus has been observed by clinical/serological methods such as PCR; approximately, 24\% and $8 \%$ of cases of with confirmed virologic maternal chickenpox respectively. Intrauterine growth restriction (IUGR) occurs in approximately $23 \%$ of cases (79) and low birth weight is universally spread (80). In a case-control study, non-exposed controls had a spontaneous preterm birth rate of $5.6 \%$ compared with $14.3 \%$ in cases of chickenpox in pregnancy $(\mathrm{P}=0.05)$. The highest mortality and morbidity rates related to chickenpox in pregnancy are associated with the presence of CVS, maternal varicella pneumonia, and neonatal varicella.

\section{Treatment of Varicella}

Varicella disease is not serious in normal children and does not require treatment. However, the disease is very fatal in infants and people with immunodeficiency and some adults, necessitating treatment. Gamma globulin, which contains a high titer of varicella-zoster antiviral antibodies, can be used for treatment. Immunoglobulin can be used to prevent the development of disease in immunocompromised patients with a history of contact with chickenpox patients. If chickenpox starts, this product will be ineffective.

\section{Varicella Diagnosis}

Chickenpox is diagnosed with skin examination without the need for specific virus testing. In a classic way, the 
virus can be removed from the surface of skin vesicles. The detection of virus DNA in vesicles is a very reliable method.

\section{Clinical Manifestations of Disease in the Fetus}

If a pregnant woman acquires chickenpox during the first half of pregnancy, her baby will be infected. In 1947, Lafart and Lynch first reported a pregnant woman suffering from chickenpox in the eighth week of pregnancy. The baby born to this woman had bone hypoplasia, eye atrophy, and hydrocephalus. If the mother's infection occurs in the first 20 weeks of pregnancy, almost $2 \%$ of this syndrome are observed and the use of varicella-zoster antiviral immunoglobulin does not reduce the risk of fetal infection. Shingles are very low in pregnant women and also is safe for the baby (81).

\section{Conclusion}

According to the study, most of the WikiLeaks virus, Zoster (VZV), is a neurotrophic Herpesvirus virus that infects most people. Host immunodeficiency even decades after the initial infection can cause the virus to re-activate itself, as a result, the ornament (zooster) is characterized by pain and rashes limited to lesions 1 to 3 . This study summarized the current knowledge of the clinical and pathological complications of neurological diseases produced by the VZV reaction, latency, virology, and specific immunity, as well as the role of apoptosis in cell death caused by VZV, and the development of an animal model built by monkey varicella virus

\section{Footnotes}

Conflict of Interests: There is no conflict of interest.

Funding/Support: This study was supported by the Zabol University of Medical Sciences, Zabol, Iran.

\section{References}

1. Tunbridge AJ, Breuer J, Jeffery KJ; British Infection Society. Chickenpox in adults - clinical management. J Infect. 2008;57(2):95-102. doi: 10.1016/j.jinf.2008.03.004. [PubMed: 18555533].

2. Gardella C, Brown ZA. Managing varicella zoster infection in pregnancy. Cleve Clin J Med. 2007;74(4):290-6. doi: 10.3949/ccjm.74.4.290. [PubMed: 17438678].

3. Civen R, Chaves SS, Jumaan A, Wu H, Mascola L, Gargiullo P, et al. The incidence and clinical characteristics of herpes zoster among children and adolescents after implementation of varicella vaccination. Pediatr Infect Dis J. 2009;28(11):954-9. doi: 10.1097/INF.0b013e3181a90b16. [PubMed: 19536039].

4. Galea SA, Sweet A, Beninger P, Steinberg SP, Larussa PS, Gershon AA, et al. The safety profile of varicella vaccine: A 10-year review. J Infect Dis. 2008;197 Suppl 2:S165-9. doi: 10.1086/522125. [PubMed: 18419392].
5. Reynolds MA, Chaves SS, Harpaz R, Lopez AS, Seward JF. The impact of the varicella vaccination program on herpes zoster epidemiology in the United States: A review. J Infect Dis. 2008;197 Suppl 2:S224-7. doi: 10.1086/522162. [PubMed: 18419401].

6. Sadzot-Delvaux C, Rentier B, Wutzler P, Asano Y, Suga S, Yoshikawa T, et al. Varicella vaccination in Japan, South Korea, and Europe.J Infect Dis. 2008;197 Suppl 2:S185-90. doi: 10.1086/522163. [PubMed: 18419395].

7. Seward JF, Marin M, Vazquez M. Varicella vaccine effectiveness in the US vaccination program: A review.J Infect Dis. 2008;197 Suppl 2:S82-9. doi: 10.1086/522145. [PubMed: 18419415].

8. Ross AH. Modification of chicken pox in family contacts by administration of gamma globulin. N Engl J Med. 1962;267:369-76. doi: 10.1056/NEJM196208232670801. [PubMed: 14494142].

9. Brunell PA, Gershon AA, Hughes WT, Riley HJ, Smith J. Prevention of varicella in high risk children: A collaborative study. Pediatrics. 1972;50(5):718-22. [PubMed: 5084186].

10. Ooi PL, Goh KT, Doraisingham S, Ling AE. Prevalence of varicella-zoster virus infection in Singapore. Southeast Asian J Trop Med Public Health. 1992;23(1):22-5. [PubMed: 1523475].

11. LaRussa P, Lungu O, Hardy I, Gershon A, Steinberg SP, Silverstein S. Restriction fragment length polymorphism of polymerase chain reaction products from vaccine and wild-type varicella-zoster virus isolates. J Virol. 1992;66(2):1016-20. [PubMed: 1346169]. [PubMed Central: PMC240804].

12. Schmader K, George LK, Burchett BM, Pieper CF, Hamilton JD. Racial differences in the occurrence of herpes zoster. J Infect Dis. 1995;171(3):701-4. doi: 10.1093/infdis/171.3.701. [PubMed: 7876622].

13. Guess HA, Broughton DD, Melton L3, Kurland LT. Epidemiology of herpes zoster in children and adolescents: A population-based study. Pediatrics. 1985;76(4):512-7. [PubMed: 3863086].

14. Hope-Simpson RE. The nature of herpes zoster: A long-term study and a new hypothesis. Proc R Soc Med. 1965;58:9-20. [PubMed: 14267505]. [PubMed Central: PMC1898279].

15. Dworsky M, Whitley R, Alford C. Herpes zoster in early infancy. Am J Dis Child. 1980;134(6):618-9. doi: 10.1001/archpedi.1980.02130180074021. [PubMed: 7386437].

16. Enders G, Miller E, Cradock-Watson J, Bolley I, Ridehalgh M. Consequences of varicella and herpes zoster in pregnancy: Prospective study of 1739 cases. Lancet. 1994;343(8912):1548-51. doi: 10.1016/s01406736(94)92943-2. [PubMed: 7802767].

17. Cohen A, Moschopoulos P, Stiehm RE, Koren G. Congenital varicella syndrome: the evidence for secondary prevention with varicella-zoster immune globulin. CMAJ. 2011;183(2):204-8. doi: 10.1503/cmaj.100615. [PubMed: 21262937]. [PubMed Central: PMC3033924].

18. Dolin R, Reichman RC, Mazur MH, Whitley RJ. NIH conference. Herpes zoster-varicella infections in immunosuppressed patients. Ann Intern Med.1978;89(3):375-88. doi: 10.7326/0003-4819-89-3-375. [PubMed: 210697].

19. Vyse AJ, Gay NJ, Hesketh LM, Morgan-Capner P, Miller E. Seroprevalence of antibody to varicella zoster virus in England and Wales in children and young adults. Epidemiol Infect. 2004;132(6):1129-34. doi: 10.1017/s0950268804003140. [PubMed: 15635971]. [PubMed Central: PMC2870205].

20. Miller E, Marshall R, Vurdien JE. Epidemiology, outcome and control of varicella-zoster infection. Rev Med Microbiol. 1993;4(4):222-30. doi: 10.1097/00013542-199310000-00006.

21. Lee BW. Review of varicella zoster seroepidemiology in India and Southeast Asia. Trop Med Int Health. 1998;3(11):886-90. [PubMed: 9855401].

22. Tan MP, Koren G. Chickenpox in pregnancy: Revisited. Reprod Toxicol. 2006;21(4):410-20. doi: 10.1016/j.reprotox.2005.04.011. [PubMed: $15979274]$. 
23. Harger JH, Ernest JM, Thurnau GR, Moawad A, Momirova V, Landon $\mathrm{MB}$, et al. Risk factors and outcome of varicella-zoster virus pneumonia in pregnant women. J Infect Dis. 2002;185(4):422-7. doi: 10.1086/338832. [PubMed: 11865393].

24. Broussard RC, Payne DK, George RB. Treatment with acyclovir of varicella pneumonia in pregnancy. Chest. 1991;99(4):1045-7. doi: 10.1378/chest.99.4.1045. [PubMed: 2009766].

25. Smego RJ, Asperilla MO. Use of acyclovir for varicella pneumonia during pregnancy. Obstet Gynecol. 1991;78(6):1112-6. [PubMed: 1945218].

26. Schutte TJ, Rogers LC, Copas PR. Varicella pneumonia complicating pregnancy: A report of seven cases. Infect Dis Obstet Gynecol. 1996;4(6):338-46. doi: 10.1155/S1064744996000683. [PubMed: 18476122]. [PubMed Central: PMC2364517].

27. Department of Health; Welsh Office; Scottish Home and Health Department; Department of Health and Social Sevices Northern Ireland. Report on confidential enquiries into maternal deaths in the United Kingdom 1985-87. London: HMSO; 1991.

28. Dworkin RH, Johnson RW, Breuer J, Gnann JW, Levin MJ, Backonja $\mathrm{M}$, et al. Recommendations for the management of herpes zoster. Clin Infect Dis. 2007;44 Suppl 1:S1-26. doi: 10.1086/510206. [PubMed: 17143845].

29. Paryani SG, Arvin AM. Intrauterine infection with varicella-zoster virus after maternal varicella. N Engl J Med. 1986;314(24):1542-6. doi: 10.1056/NEJM198606123142403. [PubMed: 3012334].

30. Higa K, Dan K, Manabe H. Varicella-zoster virus infections during pregnancy: Hypothesis concerning the mechanisms of congenital malformations. Obstet Gynecol. 1987;69(2):214-22. [PubMed: 3027637].

31. Enders G, Miller E, Arvin AM, Gershon AA. Varicella and herpes zoster in pregnancy and the newborn. Varicella- zoster virus: virology and clinical management. Cambridge Uni Press; 2000. p. 317-48. doi: 10.1017/cbo9780511601194.018.

32. Mouly F, Mirlesse V, Meritet JF, Rozenberg F, Poissonier MH, Lebon $P$, et al. Prenatal diagnosis of fetal varicella-zoster virus infection with polymerase chain reaction of amniotic fluid in 107 cases. Am J Obstet Gynecol. 1997;177(4):894-8. doi: 10.1016/s0002-9378(97)70291-6. [PubMed: 9369842].

33. Orenstein WA, Heymann DL, Ellis RJ, Rosenberg RL, Nakano J, Halsey NA, et al. Prophylaxis of varicella in high-risk children: Dose-response effect of zoster immune globulin. J Pediatr. 1981;98(3):368-73. doi: 10.1016/s0022-3476(81)80697-x. [PubMed: 7205447].

34. Brunell PA. Transmission of chickenpox in a school setting prior to the observed exanthem. Am J Dis Child. 1989;143(12):1451-2. doi: 10.1001/archpedi.1989.02150240073020. [PubMed: 2556025].

35. Grose C. Varicella infection during pregnancy. Herpes. 1999;6(2):33-7.

36. Smith CK, Arvin AM. Varicella in the fetus and newborn. Semin Fetal Neonatal Med. 2009;14(4):209-17. doi: 10.1016/j.siny.2008.11.008. [PubMed: 19097954].

37. Bhardwaj A, Sharma P, Sharma A. Neonatal varicella: A case report. Australas Med J. 2011;4(6):291-3. doi: 10.4066/AMJ.2011.682. [PubMed: 23386890]. [PubMed Central: PMC3562945].

38. Wutzler P, Farber I, Wagenpfeil S, Bisanz H, Tischer A. Seroprevalence of varicella-zoster virus in the German population. Vaccine. 2001;20(12):121-4. doi: 10.1016/s0264-410x(01)00276-6. [PubMed: 11567755].

39. de Melker H, Berbers G, Hahne S, Rumke H, van den Hof S, de Wit A, et al. The epidemiology of varicella and herpes zoster in The Netherlands: Implications for varicella zoster virus vaccination. Vaccine. 2006;24(18):3946-52. doi: 10.1016/j.vaccine.2006.02.017. [PubMed:16564115].

40. Marin M, Meissner HC, Seward JF. Varicella prevention in the United States: A review of successes and challenges. Pediatrics. 2008;122(3):e744-51. doi: 10.1542/peds.2008-0567. [PubMed: 18762511].

41. Ziyaeyan M, Alborzi A, Jamalidoust M, Moieni M, Pourabbas B. Seroepidemiology of varicella zoster virus infection among 1-70 year individuals in Iran. Iran Red Crescent Med J. 2010;12(2):176.

42. Taghavi Ardakani A, Soltani B, Sehat M, Namjoo S. Seroprevalence and risk factors of varicella-zoster among children of Kashan- center of
Iran.Jundishapur J Microbiol. 2013;6(5). e8388. doi:10.5812/jjm.8388.

43. Ehsanipour F, Shayanfar N, Salariyan K. Surveying of protective antibody against varicella zoster virus (VZV) infection in children referring to Hazrat-e-Rasool Akram Hospital (2005). Razi J Med Sci. 2009;16:0.

44. Motamedifar M, Handijani F, Hadi N, Shahkarami MK, Mehrabani D Seroprevalence of varicella-zoster virus in children from Shiraz-Iran. Iran J Immunol. 2006;3(1):43-6.

45. Akram DS, Qureshi H, Mahmud A, Khan AA, Kundi Z, Shafi S, et al. Seroepidemiology of varicella-zoster in Pakistan. Southeast Asian J Trop Med Public Health. 2000;31(4):646-9. [PubMed: 11414405].

46. Migasena S, Simasathien S, Desakorn V, Phonrat B, Suntharasamai P, Pitisuttitham P, et al. Seroprevalence of varicella-zoster virus antibody in Thailand. Int J Infect Dis. 1997;2(1):26-30. doi: 10.1016/s12019712(97)90007-2.

47. Aebi C, Fischer K, Gorgievski M, Matter L, Muhlemann K. Age-specific seroprevalence to varicella-zoster virus: study in Swiss children and analysis of European data. Vaccine. 2001;19(23-24):3097-103. doi 10.1016/s0264-410x(01)00035-4. [PubMed: 11312004].

48. Kanra G, Tezcan S, Badur S, Turkish National Study T. Varicella seroprevalence in a random sample of the Turkish population. Vaccine. 2002;20(9-10):1425-8. doi: 10.1016/s0264-410x(01)00459-5. [PubMed 11818162].

49. Uduman SA, Tahira AM, Al-Wash R, Usmani MA, Bener A. Varicella susceptibility among children and healthy adults in the United Arab Emirates. East Mediterr Health J. 2001;7(4-5):604-8. [PubMed: 15332755].

50. Brisson M, Edmunds WJ. Epidemiology of Varicella-Zoster Virus in England and Wales. J Med Virol. 2003;70 Suppl 1:S9-14. doi: 10.1002/jmv.10313. [PubMed: 12627480].

51. Lin F, Hadler JL. Epidemiology of primary varicella and herpes zoster hospitalizations: The pre-varicella vaccine era. J Infect Dis 2000;181(6):1897-905. doi:10.1086/315492. [PubMed:10837168].

52. Onozawa M, Hashino S, Haseyama Y, Hirayama Y, Iizuka S, Ishida $\mathrm{T}$, et al. Incidence and risk of postherpetic neuralgia after varicella zoster virus infection in hematopoietic cell transplantation recipients: Hokkaido Hematology Study Group. Biol Blood Marrow Transplant. 2009;15(6):724-9. doi: 10.1016/j.bbmt.2009.03.003. [PubMed 19450757].

53. Creed R, Satyaprakash A, Ravanfar P. Varicella zoster vaccines Dermatol Ther. 2009;22(2):143-9. doi: 10.1111/j.1529-8019.2009.01226.x. [PubMed: 19335725].

54. Gelb LD. Varicella zoster virus redux. Herpes. 2009;15(3):62-3. [PubMed: 19306605].

55. Sampathkumar P, Drage LA, Martin DP. Herpes zoster (shingles) and postherpetic neuralgia. Mayo Clin Proc. 2009;84(3):274-80. doi: 10.1016/S0025-6196(11)61146-4. [PubMed: 19252116]. [PubMed Central: PMC2664599].

56. Mandell GL, Douglas GR, Bennett JE. Principal and practice of infectious diseases. 5th ed. Philadelphia, Churchill Livingston; 2000.

57. Nilsson A, Ortqvist A. Severe varicella pneumonia in adults in Stockholm County 1980-1989. Scand J Infect Dis. 1996;28(2):121-3. doi: 10.3109/00365549609049061. [PubMed: 8792476].

58. Mohsen AH, Peck RJ, Mason Z, Mattock L, McKendrick MW. Lung function tests and risk factors for pneumonia in adults with chickenpox.Thorax.2001;56(10):796-9. doi: 10.1136/thorax.56.10.796. [PubMed: 11562520]. [PubMed Central: PMC1745928].

59. Paryani SG, Arvin AM, Koropchak CM, Dobkin MB, Wittek AE, Amylon $\mathrm{MD}$, et al. Comparison of varicella zoster antibody titers in patients given intravenous immune serum globulin or varicella zoster immune globulin. J Pediatr. 1984;105(2):200-5. doi: 10.1016/s00223476(84)80113-4. [PubMed: 6086866].

60. Popara M, Pendle S, Sacks L, Smego RJ, Mer M. Varicella pneumonia in patients with HIV/AIDS. Int J Infect Dis. 2002;6(1):6-8. [PubMed: 12044294].

61. El-Daher N, Magnussen CR, Betts RE. Varicella pneumonitis: Clinical 
presentation and experience with acyclovir treatment in immunocompetent adults. Int J Infect Dis. 1998;2(3):147-51. doi: 10.1016/s12019712(98)90117-5.

62. Weinstein L. Respiratory manifestations of Chicken Pox. Arch Intern Med.1956;98(1):91-9. doi:10.1001/archinte.1956.00250250097013.

63. Baren JM, Henneman PL, Lewis RJ. Primary varicella in adults: pneumonia, pregnancy, and hospital admission. Ann Emerg Med. 1996;28(2):165-9. doi: 10.1016/s0196-0644(96)70057-4. [PubMed: 8759580].

64. Hockberger RS, Rothstein RJ. Varicella pneumonia in adults: A spectrum of disease. Ann Emerg Med. 1986;15(8):931-4. doi: 10.1016/s01960644(86)80679-5. [PubMed: 3740580].

65. Rose RM, Wasserman AS, Weiser WY, Remold HG. Deficient responses of pulmonary macrophages from healthy smokers to antiviral lymphokines in vitro. J Infect Dis. 1986;154(4):611-8. doi: 10.1093/infdis/154.4.611. [PubMed: 3018094].

66. WHO. Varicella and herpes zoster vaccines: WHO position paper, June 2014-Recommendations. Vaccine. 2016;34(2):198-9. doi 10.1016/j.vaccine.2014.07.068. [PubMed: 26723191].

67. Kreth HW, Lee BW, Kosuwon P, Salazar J, Gloriani-Barzaga N, Bock HL, et al. Sixteen years of global experience with the first refrigeratorstable varicella vaccine (Varilrix). BioDrugs. 2008;22(6):387-402. doi: 10.2165/0063030-200822060-00005. [PubMed: 18998756].

68. Bonanni P, Gershon A, Gershon M, Kulcsar A, Papaevangelou V, Rentier B, et al. Primary versus secondary failure after varicella vaccination: Implications for interval between 2 doses. Pediatr Infect Dis J. 2013;32(7):e305-13. doi: 10.1097/INF.0b013e31828b7def. [PubMed 23838789]. [PubMed Central: PMC5500254].

69. Marin M, Guris D, Chaves SS, Schmid S, Seward JF; Advisory Committee on Immunization Practices Centers for Disease Control, et al. Prevention of varicella: Recommendations of the Advisory Committee on Immunization Practices (ACIP). MMWR Recomm Rep. 2007;56(RR4):1-40. [PubMed: 17585291].

70. Kurugol Z, Halicioglu O, Koc F, Koturoglu G, Aksit S. Varicella rates among unvaccinated and one-dose vaccinated healthy children in Izmir, Turkey. Int I Infect Dis. 2011;15(7):e475-80. doi: 10.1016/j.ijid.2011.03.016. [PubMed: 21592838].

71. Tafuri S, Martinelli D, De Palma M, Germinario C, Prato R. Report of varicella outbreak in a low vaccination coverage group of otherwise healthy children in Italy: The role of breakthrough and the need of a second dose of vaccine. Vaccine. 2010;28(6):1594-7. doi: 10.1016/j.vaccine.2009.11.047. [PubMed:19961965].

72. Banz K, Iseli A, Aebi C, Brunner M, Schmutz AM, Heininger U. Economic evaluation of varicella vaccination in Swiss children and adolescents. Hum Vaccin. 2009;5(12):847-57. doi: 10.4161/hv.9898. [PubMed: 19829048].

73. Maman K, Zollner Y, Greco D, Duru G, Sendyona S, Remy V. The value of childhood combination vaccines: From beliefs to evidence. Hum Vaccin Immunother. 2015;11(9):2132-41. doi: 10.1080/21645515.2015.1044180. [PubMed: 26075806]. [PubMed Central: PMC4635899].

74. Holl K, Sauboin C, Amodio E, Bonanni P, Gabutti G. Coverage, efficacy or dosing interval: Which factor predominantly influences the impact of routine childhood vaccination for the prevention of varicella? A model-based study for Italy. BMC Public Health. 2016;16(1):1103. doi: 10.1186/s12889-016-3738-x. [PubMed: 27769206]. [PubMed Central: PMC5073465].

75. Zaia JA, Levin MJ, Preblud SR, Leszczynski J, Wright GG, Ellis RJ, et al. Evaluation of varicella-zoster immune globulin: Protection of immunosuppressed children after household exposure to varicella. $J$ Infect Dis. 1983;147(4):737-43. doi: 10.1093/infdis/147.4.737. [PubMed: 6341478].

76. Koren G, Money D, Boucher M, Aoki F, Petric M, Innocencion G, et al. Serum concentrations, efficacy, and safety of a new, intravenously administered varicella zoster immune globulin in pregnant women. J Clin Pharmacol. 2002;42(3):267-74. doi: 10.1177/00912700222011283. [PubMed: 11865962].

77. Jones KL, Johnson KA, Chambers CD. Offspring of women infected with varicella during pregnancy: A prospective study. Teratology. 1994;49(1):29-32. doi:10.1002/tera.1420490106. [PubMed: 8171394].

78. Sauerbrei A, Wutzler P. Varicella-zoster virus infections during pregnancy: Epidemiology, clinical symptoms, diagnosis, prevention and therapy. Cur Pediatr Rev. 2005;1(3):205-15. doi: $10.2174 / 157339605774574962$.

79. Sauerbrei A, Wutzler P. Fetales varizellensyndrom. Monatsschrift Kinderheilkunde. 2003;151(2):209-13. doi: 10.1007/s00112-002-0478-z.

80. Birthistle K, Carrington D. Fetal Varicella syndrome - a reappraisal of the literature.JInfect.1998;36:25-9. doi:10.1016/s0163-4453(98)80152-7.

81. Marodi L. Neonatal innate immunity to infectious agents. Infect Immun. 2006;74(4):1999-2006. doi: 10.1128/IAI.74.4.1999-2006.2006. [PubMed: 16552028]. [PubMed Central: PMC1418902]. 